\title{
Genetic Diversity in Insect Metal Tolerance
}

\author{
Thomas J. S. Merritt ${ }^{1 *}$ and Adam J. Bewick ${ }^{2}$ \\ ${ }^{1}$ Department of Chemistry and Biochemistry, Laurentian University, Sudbury, ON, Canada, ${ }^{2}$ Department of Genetics, \\ University of Georgia, Athens, GA, United States
}

Insects encounter a variety of metals in their environment, many of which are required at some concentration for normal organismal homeostasis, but essentially all of which are toxic at higher concentrations. Insects have evolved a variety of genetic, and likely epigenetic, mechanisms to deal with metal stress. A recurring theme in all these systems is complexity and diversity; even simple, single gene, cases are complex. Of the known gene families, the metallothioneins are perhaps the best understood and provide good examples of how diverse metal response is. Interestingly, there is considerable diversity across taxa in these metal-responsive systems, including duplications to form small gene families and complex expression of single loci. Strikingly, different species have evolved different mechanisms to cope with the same, or similar, stress suggesting both independent derivation of, and plasticity in, the pathways involved. It is likely that some metal-response systems evolved early in evolutionary time and have been conserved,

OPEN ACCESS

Edited by:

Stephanie Mohr,

Harvard Medical School,

United States

Reviewed by:

Steven Marygold,

University of Cambridge,

United Kingdom

Juan-Carlos Gutierrez,

Complutense University of Madrid

Spain

*Correspondence:

Thomas J. S. Merritt

tmerritt@/aurentian.ca

Specialty section:

This article was submitted to

Toxicogenomics,

a section of the journal

Frontiers in Genetics

Received: 21 September 2017

Accepted: 23 October 2017

Published: 07 November 2017

Citation:

Merritt TJS and Bewick AJ (2017)

Genetic Diversity in Insect Metal

Tolerance. Front. Genet. 8:172.

doi: 10.3389/fgene.2017.00172 while others have diverged, and still others evolved more recently and convergently. In addition to conventional genetics, insects likely respond to environmental metal through a variety of epigenetic systems, but direct tests are lacking. Ultimately, it is likely that classical genetic and epigenetic factors interact in regulating insect metal responses. In light of this diversity across species, future studies including a broad-based examination of gene expression in non-model species in complex environments will likely uncover additional genes and genetic and epigenetic mechanisms.

Keywords: insect metal response, metallothionein, antioxidant metabolic enzymes, epigenetic regulation, $A B C$ transporter genes

\section{INTRODUCTION}

Insects respond to environmental metals in multiple ways; here we highlight the genetics of this response and focus on the diversity of responses including different genes, gene families, and epigenetic responses.

\section{Metal Biology}

Metals present a biological challenge in that many are absolutely required for various cellular functions, but higher concentrations are generally toxic (Southon et al., 2013). Organisms must carefully balance metal uptake, exclusion, and excretion to ensure that metals are present in sufficient, but not toxic, concentrations. Biological metal concentrations are, however, low and environmental exposure issues are generally issues of contamination leading to excess metals and toxicity. The genetics of metal response and detoxification is strikingly dynamic with independent evolution of different mechanisms to achieve this balance across animals and even specifically within insects. 
Metals have a suite of biochemical functions and metal responses are similarly diverse. Many metals, e.g., iron $(\mathrm{Fe})$, copper $(\mathrm{Cu})$, chromium $(\mathrm{Cr})$, manganese $(\mathrm{Mn})$, and zinc $(\mathrm{Zn})$ have key biological roles including functions in energy production, carbohydrate and lipid metabolism, and gene regulation (Bondy, 2016). Excesses of these metals, however, have both direct and indirect toxic effects (Valko et al., 2005; Southon et al., 2013). High concentrations of metals bind to DNA causing direct damage or disrupting gene expression. Heavy metals can displace essential metals and, for example, disrupt enzyme function. Such disruption can lead to oxidative stress (OS) and a suite of changes in gene expression. Metal toxicity can also result from OS caused by redox cycling metals, e.g., Fe and $\mathrm{Cu}$, directly promoting generation of reactive oxygen species (ROS) and reactive nitrogen species (RNS; Valko et al., 2005, 2015). Similarly, even metals that are redox inert can result in OS toxicity by depleting antioxidants such as glutathione or by direct binding to proteins through sulfhydryl groups (Valko et al., 2015).

\section{Gene Systems}

Dynamism is a defining characteristic of the genetics of metal response with a diversity of genes and mechanisms present across taxa. Some systems appear to be evolutionarily ancient while others are more recent adaptations and can be variable even within populations. Laboratory, studies of the physiological responses to exposure to high-metal concentrations have identified a series of metal-responsive genes. These genes function to maintain metal balance by sequestering metals and promoting their expulsion from the organism and are up regulated in response to high metal concentrations. Changes in gene expression can be functions of binding of regulatory factors, changes in chromatin accessibility or transcript stability (Janssens et al., 2009). The changes in gene expression either result directly from metal binding or indirectly through changes in redox state (Valko et al., 2005, 2015). In addition, protein concentration and activity can be modified by control of translation or posttranslational regulation or stability (Janssens et al., 2009).

Metal-responsive genes have also been identified through evolutionary studies of adaptation to high metal environments. Metal tolerance has evolved in a variety of insects with interesting differences that likely reflect differences in life history and ecology. Environmental metals are often highly persistent, placing long-term selective pressures on local populations (Stone et al., 2001; Migula et al., 2004). Lacking the ability to relocate, low dispersal organisms can be continuously exposed to metals for many generations placing a high selective pressure on adaptation through genetic mechanisms, with stress-resistant members of a population more reproductively successful in contaminated sites (Migula et al., 2004). Conversely, high dispersal organisms may not develop metal tolerance as dispersal can prevent local adaptation. Evolutionary studies explore standing genetic diversity in populations and complement physiological studies, generally identifying similar genes or pathways, but with the potential to uncover novel systems especially as more diverse taxa and environments are incorporated into studies. Such an evolutionary approach identified a broad, transcriptome-wide, metal response in springtails, Orchesella cincta, invertebrate hexapods, from contaminated mine sites (Roelofs et al., 2009). Individuals from control and contaminated sites were exposed to cadmium $(\mathrm{Cd})$ in the laboratory and the reference population, but not the tolerant population, showed a strong transcriptomewide stress response. Further, some stress-responsive genes were less inducible in tolerant springtails, suggesting that these genes were already overexpressed in this population. These differences in expression are likely evolutionary adaptation of the population from the contaminated site; changes in gene regulation that make a major contribution to the evolution of a stress-adapted phenotype.

Fundamentally, organisms have limited energy supplies and there are costs to living in stressful environments, even "tolerant" organisms must expend metabolic resources in accommodating stressors (e.g., the metabolic cost of sequestering or expelling excess metals; Stone et al., 2001; Morgan et al., 2007). Resistant individuals are better able to handle this stress, but resistance likely comes at a cost. For example, in the absence of metal contamination, metal tolerant mosquitoes have significantly lower viability, survivorship, and fecundity than controls; their adaptations to high metal are physiological burdens in the absence of metals (Mireji et al., 2010b). In addition, metal stress can limit an organism's ability to cope with other stressors and studies of multiple stressors have led to discoveries of novel mechanisms. For example, while carabid beetles living in a pollution gradient with high levels of $\mathrm{Zn}, \mathrm{Cd}, \mathrm{Cu}$, and lead $\mathrm{Pb})$ were phenotypically indistinguishable from controls, they were less tolerant to desiccation or pesticide exposure (Stone et al., 2001). Multiple stressors had a profound effect; the stressed population was more susceptible to additional stressors, but it was unclear if this was a physiological effect or a function of reduction in genetic variability in the population as a result of long-term contamination. This cost of resistance may, in part, account for the dynamic nature of many genetic mechanisms of metal tolerance.

In addition to highlighting the compounding effects of multiple stressors, evolutionary studies also indicate that responses to different metal stressors may be distinct and complicated, with limited overlap. A laboratory study of. magna (Crustacea) exposed to $\mathrm{Cu}, \mathrm{Cd}$, or $\mathrm{Zn}$, found a broad suite of genetic changes, but only four genes that were differentially expressed under all three metals; the different metal stressors resulted in distinct responses (Poynton et al., 2007). A similar study of Fundulus heteroclitus (Actinopterygii) exposed to a suite of contaminants showed broad changes in gene expression in different populations with only limited convergence: only two genes changed expression in all three comparisons and only one of these changed in the same direction (Fisher and Oleksiak, 2007). Limited parallel responses to metal stressors are observed between insects. Initial studies of the evolution of insecticide resistance, a stressor similar to metal contamination, in Drosophila melanogaster (Daborn et al., 2002; Le Goff et al., 2003), suggested that resistance was a single-gene phenomenon. However, later studies indicate that multiple genes are likely involved (Pedra et al., 2004; Schmidt et al., 2010; van Straalen et al., 2011). Additionally, populations do not necessarily adapt to a high metal environment. For example, 10 generations of 
high exposure to $\mathrm{Cd}$ or $\mathrm{Zn}$ led to only a moderate increase in $\mathrm{Cd}$ tolerance, no $\mathrm{Zn}$ tolerance, and no evidence for cross-resistance in Spodoptera exigua moths (Kafel et al., 2014). Furthermore, moths from high $\mathrm{Zn}$ exposure were less tolerant to $\mathrm{Zn}$, possibly reflecting long-term physiological stress and an inability to adapt to the stressor.

Substantial genetic diversity in environmental metal response, within and between, species is a recurring theme in these studies. Different species respond differently to the same stressors and different stressors elicit different responses within a single species and across species. Metal tolerance is rarely, if ever, a single gene affair, and a network view is most appropriate (van Straalen et al., 2011). This point notwithstanding, a few key genes and gene families have repeatedly been found to be involved in metal tolerance (Table 1).

\section{CLASSICAL GENETIC RESPONSES}

\section{Metallothioneins (MTs)}

Metallothioneins (MT), small, cysteine-rich, proteins that bind metals including $\mathrm{Cu}, \mathrm{Zn}$, and $\mathrm{Cd}$ through metal-thiolate bridges, are one of the more thoroughly studied metal-responsive gene families (Kägi, 1991). MT gene expression is up-regulated by metals in a variety of taxa and MT gene expression has been developed as a biomarker of metal contamination in insects and other animals (Mireji et al., 2010a; M'kandawire et al., 2017). MTs are ubiquitous in eukaryotes, generally present as multi-gene families; e.g., D. melanogaster have at least five (Atanesyan et al., 2011) and mosquitoes (Anopheles gambiae) at least two (Shaw et al., 2007). These gene families likely allow functional specialization. Specific loci are differentially regulated, at both transcription and translation (Janssens et al., 2009; Mireji et al., 2010a), with specific loci expressed in response to different stimuli in specific tissues and developmental stages (Atanesyan et al., 2011; Baurand et al., 2015; Qiang et al., 2017). Different MT proteins also have distinct biochemistry, at least in Escherichia coli expression systems (Achard-Joris et al., 2007). Interestingly, diversity within these gene families appears to have evolved independently in different taxonomic groups, through independent evolutionary radiations and losses, not an early diversification (Guirola et al., 2010). Even within insects and other invertebrates, the MT gene family is highly diverse likely the result of independent evolutionary events and convergence on a shared pattern of diversity (Shaw et al., 2007; Janssens et al., 2009).

Metallothioneins are well studied in D. melanogaster (e.g., Egli et al., 2006; Guirola et al., 2010; Atanesyan et al., 2011). These flies have five known $M t$ loci, MtnA, MtnB, MtnC, MtnD, MtnE (Atanesyan et al., 2011; Qiang et al., 2017). These loci are all induced by a shared transcription factor and shared promoter response element, but each has distinct expression patterns and likely distinct, but possibly overlapping, functions (Egli et al., 2006; Atanesyan et al., 2011; Qiang et al., 2017). Interestingly, given the diversity of this gene family across taxa, the five loci, and their expression products are conserved across 12 species of Drosophila (Guirola et al., 2010); the family can remain stable across considerable evolutionary time. The D. melanogaster MT loci are all primarily expressed in the intestine, but the different loci appear to respond to different metals, e.g., MtnA is preferentially induced by $\mathrm{Cu}$ and $\mathrm{MtnB}$ by $\mathrm{Cd}$ (Atanesyan et al., 2011; Qiang et al., 2017). The variable gene expression is reflected in different amounts of protein and the proteins have distinct biochemical characteristics, e.g., distinct binding affinities for $\mathrm{Zn}, \mathrm{Cd}$, and $\mathrm{Cu}$ (Egli et al., 2006; Qiang et al., 2017). MtnE, is the most recent D. melanogaster locus to be described (Atanesyan et al., 2011), has the broadest metal binding affinity, and may be a general-metal response element (PérezRafael et al., 2012). MtnB gene expression, and $M t n B$ mutant flies, were sensitive to $\mathrm{Cu}, \mathrm{Cd}$, and $\mathrm{Zn} . \mathrm{Mtn} B, M \operatorname{tn} C$, and $M t n D$ expression also respond to elevated Fe levels (Qiang et al., 2017), but this response is indirect, a result of interruption of protein interactions with other metals, such as $\mathrm{Zn}$, highlighting that metal toxicity can result from more complicated interactions than simple direct metal binding or displacement, adding an additional level of complexity to the genetics of metal response (Qiang et al., 2017). Further, expression of MT proteins has also been associated with induction, rather than repression, of OS, possibly a function of release under oxidizing physiological conditions of MT-bound metals that then interact with the superoxide dismutase (SOD) system (Achard-Joris et al., 2007). This counterintuitive association of a metal-tolerance gene family with induction of OS further highlights the complexity of these stress response elements.

Metallothioneins have also been studied in other insects and invertebrates. Expression of at least one of the two mosquito MT loci responds to $\mathrm{Cd}$ and $\mathrm{Pb}$ (Mireji et al., 2010a). Interestingly, in contrast to the multiple loci in fruit flies and mosquitoes, the springtail invertebrate hexapod, Orchesella cincta, has a single MT locus. Expression of this single locus is metal-responsive and expression differences appear to reflect local adaptation to metal contamination (Janssens et al., 2009; Roelofs et al., 2009; van Straalen et al., 2011). Further, regulatory variation in the O. cincta MT gene is sensitive to genetic background, i.e., an allele behaves differently in different backgrounds, indicating that expression is modified by trans-acting factors (van Straalen et al., 2011) and highlighting that even this "simple" system is complex, the function of multiple genes.

\section{Antioxidant Metabolic Enzymes}

Metal exposure is associated with OS and antioxidant enzymes have a substantial role in insect metal response. Metal exposure variously results in either enhancement or inhibition of antioxidant enzymes including mitochondrial and cytosolic SOD, catalase (CAT), and Glutathione-Stransferase (GST; Migula et al., 2004). Aluminum (Al) toxicity in D. melanogaster is a function of interactions with $\mathrm{Fe}$, is mediated by ROS production, and results in increased expression of mitochondrial SOD, but not cytosolic SOD and is suppressed by overexpression of CAT, but not SOD (Wu et al., 2012) again highlighting the potential for indirect interactions and the complexity of genetic responses. Beetles exposed to a complex mix of pollutants including high levels of $\mathrm{Pb}, \mathrm{Zn}, \mathrm{Cd}$, and $\mathrm{Cu}$, had significant changes in the activities 
TABLE 1 | Metal responsive genes in insects.

\begin{tabular}{|c|c|c|}
\hline Gene family & Species & $\begin{array}{l}\text { Known interacting } \\
\text { metals }\end{array}$ \\
\hline Metallothioneins & Drosophila melanogaster ${ }^{1,2}$, Anopholese gambiae ${ }^{3,4}$, Orcista cincta $^{5}$ & $\mathrm{Cu}, \mathrm{Cd}, \mathrm{Zn}$ \\
\hline Cytosolic superoxide dismutase & $\begin{array}{l}\text { Pterostichus oblongopunctatus, Geotrupes stercorosus, Staphylinus caesareus, } \\
\text { Phyllobius betulae } 6\end{array}$ & $\mathrm{~Pb}, \mathrm{Zn}, \mathrm{Cu}, \mathrm{Cd}$ \\
\hline $\begin{array}{l}\text { Mitochondrial superoxide } \\
\text { dismutase }\end{array}$ & Drosophila melanogaster ${ }^{7}$ & $\mathrm{Al}, \mathrm{Fe}$ \\
\hline Catalase & $\begin{array}{l}\text { Pterostichus oblongopunctatus, Geotrupes stercorosus, Staphylinus caesareus, } \\
\text { Phyllobius betulae }^{6} \text {, Drosophila melanogaster }\end{array}$ & $\mathrm{Pb}, \mathrm{Zn}, \mathrm{Cu}, \mathrm{Cd}$ \\
\hline Glutathione-S-transferase & $\begin{array}{l}\text { Pterostichus oblongopunctatus, Geotrupes stercorosus, Staphylinus caesareus, } \\
\text { Phyllobius betulae } 6\end{array}$ & $\mathrm{~Pb}, \mathrm{Zn}, \mathrm{Cu}, \mathrm{Cd}$ \\
\hline Glutathione reductase & $\begin{array}{l}\text { Pterostichus oblongopunctatus, Geotrupes stercorosus, Staphylinus caesareus, } \\
\text { Phyllobius betulae } 6\end{array}$ & $\mathrm{~Pb}, \mathrm{Zn}, \mathrm{Cu}, \mathrm{Cd}$ \\
\hline $\begin{array}{l}\text { Se-dependent glutathione } \\
\text { peroxidase }\end{array}$ & $\begin{array}{l}\text { Pterostichus oblongopunctatus, Geotrupes stercorosus, Staphylinus caesareus, } \\
\text { Phyllobius betulae } 6\end{array}$ & $\mathrm{~Pb}, \mathrm{Zn}, \mathrm{Cu}, \mathrm{Cd}$ \\
\hline $\begin{array}{l}\text { Se-independent glutathione } \\
\text { peroxidase }\end{array}$ & $\begin{array}{l}\text { Pterostichus oblongopunctatus, Geotrupes stercorosus, Staphylinus caesareus, } \\
\text { Phyllobius betulae } 6\end{array}$ & $\mathrm{~Pb}, \mathrm{Zn}, \mathrm{Cu}, \mathrm{Cd}$ \\
\hline ABC transporter proteins & Drosophila melanogaster ${ }^{8}$, Lygus hesperus $^{9}$ & $\mathrm{Cd}$ \\
\hline$\alpha$-tubulin & Anopholese gambiae ${ }^{3}$, Chironomus tentans ${ }^{10}$ & $\mathrm{Cu}, \mathrm{Pb}, \mathrm{Cd}$ \\
\hline CYP6 & Anopholese gambiae ${ }^{11}$ & $\mathrm{Cd}, \mathrm{Pb}$ \\
\hline
\end{tabular}

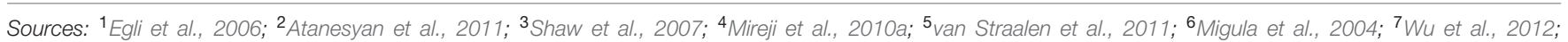
${ }^{8}$ Sooksa-Nguan et al., 2009; ${ }^{9}$ Hull et al., 2014; ${ }^{10}$ Mattingly et al., 2001; ${ }^{11}$ Musasia et al., 2013.

of antioxidant enzymes (Migula et al., 2004), but different species responded differently, possibly reflecting differences in life history leading to different effective exposures, or differences in genetic response in each species, or both. While exact responses differed across species, in general SOD activity was high, and CAT activity low, in highly contaminated areas and activity of glutathione enzymes were more variable. Strikingly, all enzyme activities were most variable in highly contaminated environments; stressful environments expose biological variability (Migula et al., 2004). This is exactly the kind of variability that would be required for evolutionary adaptation of these stressful environments (van Straalen et al., 2011).

\section{Additional Gene Families}

A wide variety of other genes and gene families have been directly or indirectly implicated in insect metal response (Calap-Quintana et al., 2017). The ATP-binding cassette (ABC) transporter proteins, a large family of membrane proteins characterized by an ATP-binding cassette, have a variety of biological roles, including metal detoxification. Metal-responsive $\mathrm{ABC}$ transporter genes are present in insects (Sooksa-Nguan et al., 2009; Hull et al., 2014) and, in D. melanogaster, increased gene expression is associated with tolerance to metal exposure (Sooksa-Nguan et al., 2009). Cadmium and Pb tolerant A. gambiae mosquitoes have significant reduction in expression of the CYP6 family of cytochrome p450 genes, a gene family associated with resistance to pyrethroid pesticides (Musasia et al., 2013), suggesting potential interactions between metal tolerance and pesticide sensitivity. Expression of the alpha-tubulin gene also responds to metal concentrations in both A. gambiae (Mireji et al., 2010a) and Chironomus tentans midges (Mattingly et al., 2001). This is not an exhaustive list, and as more efforts are put in to broad-based exploratory studies (see below) it will continue to grow.

\section{EPIGENETIC SYSTEMS}

Insect metal response likely extends beyond classical genetics to epigenetics - inherited phenotypic change that is not solely due to a change in DNA sequence. Epigenetic changes appear to contribute to metal tolerance in both animals (Salnikow and Zhitkovich, 2008) and plants (Hanikenne and Nouet, 2011), but have yet to be functionally tested in insects. DNA methylation to the 5 th atom of cytosine (5-methylcytosine; $5 \mathrm{mC}$ ) is a relatively well-studied epigenetic modification in other organisms, and an attractive modification to test for an epigenetic component to metal stress in insects. In mouse cells, for example, $5 \mathrm{mC}$ variation at the promoter of a MT gene causes differences in expression; $5 \mathrm{mC}$ changes histone associations and represses gene expression (Majumber et al., 2006). Additionally, in the plant Arabidopsis thaliana, $5 \mathrm{mC}$ variation is associated with variation for biotrophic bacterial pathogen resistance (Reinders et al., 2009). However, $5 \mathrm{mC}$ is absent from D. melanogaster, and Diptera universally (Raddatz et al., 2013; Bewick et al., 2016), hindering functional testing and leading to speculation that epigenetic regulation by $5 \mathrm{mC}$ has a smaller role in insects. Species belonging to other orders of insects do, however, possess varying levels and genomic locations of $5 \mathrm{mC}$ (Kharchenko et al., 2011; Bewick et al., 2016; Glastad et al., 2016a,b, 2017). The functional importance of this variation specifically in response to metals, and stress generally, has yet to be tested. However, tractable species for epigenetic functional studies have been recently identified. An insect epigenetic response to metal stress will likely be complex, but systems and tools are now at hand to move insect functional epigenetics forward (Trible et al., 2017). 


\section{FUTURE DIRECTIONS}

Complexity of genes, gene families and regulatory mechanisms is a recurring theme in insect metal response. Our current understanding strongly suggests that even more complex systems exist and calls for broad-based exploration across species taking advantage of recent technical advantages in transcriptomics, proteomics, and metabolomics (Morgan et al., 2007; Poynton et al., 2007; Shaw et al., 2007; Soetaert et al., 2007). The last two fields are particularly understudied although recent work indicates that moving beyond the transcriptome can uncover unexpected, but biologically important, interactions (e.g., Knee et al., 2013; MacMillan et al., 2016).

The evolution of different metal-tolerance mechanisms also suggests that we need to explore both with established model systems and novel systems. Recent advances in gene editing technologies should open up such novel systems for study (Janssens et al., 2009). In addition, existing work indicates that multiple stressors result in different responses than single

\section{REFERENCES}

Achard-Joris, M., Moreau, J. -L., Lucas, M., Baudrimont, M., Mesmer-Dudons, N, Gonzalez, P., Boudou, A., and Bourdineaud, J. -P. (2007). Role of metallothioneins in superoxide radical generation during copper redox cycling: defining the fundamental function of metallothioneins. Biochimie 89, 1474-1488. doi: 10.1016/j.biochi.2007.06.005

Alvarez, M, Schrey, A. W., and Richards, C. L. (2015). Ten years of transcriptomics in wild populations: what have we learned about their ecology and evolution? Mol. Ecol. 24, 710-725. doi: 10.1111/mec.13055

Atanesyan, L., Günther, V., Celniker, S. E., Georgiev, O., and Schaffner, W. (2011). Characterization of MtnE, the fifth metallothionein member in Drosophila. J. Biol. Inorg. Chem. 16, 1047-1056. doi: 10.1007/s00775-011-0825-4

Baurand, P.-E., Pedrini-Martha, V., de Vaufleury, A., Niederwanger, M., Capelli, N., Scheifler, R., and Dallinger, R. (2015). Differential expression of metallothionein isoforms in terrestrial snail embryos reflects early life stage adaptation to metal stress. PLOS ONE 10:e0116004. doi: 10.1371/journal.pone. 0116004

Bewick, A. J., Vogel, K. J., Moore, A. J., and Schmitz, R. J. (2016). Evolution of DNA methylation across insects. Mol. Biol. Evol. 34, 654-665. doi: 10.1093/molbev/ msw264

Bondy, S. C. (2016). "Metal toxicity, inflammation and oxidative stress" in Inflammation, Aging, and Oxidative Stress Oxidative Stress in Applied Basic Research and Clinical Practice, eds S. Bondy, A. Campbell (Cham: Springer International Publishing), 3-16.

Calap-Quintana, P., González-Fernández, J., Sebastiá-Ortega, N., Llorens, J., and Moltó, M. (2017). Drosophila melanogaster models of metal-related human diseases and metal toxicity. Int. J. Mol. Sci. 18:E1456. doi: 10.3390/ijms18 071456

Colbourne, J. K., Pfrender, M. E., Gilbert, D., Thomas, W. K., Tucker, A., Oakley, T. H., Tokishita, S., et al. (2011). The ecoresponsive genome of Daphnia pulex. Science 331, 555-561. doi: 10.1126/science.1197761

Daborn, P. J., Yen, J. L., Bogwitz, M. R., Le Goff, G., Feil, E., Jeffers, S., Tijet, N., et al. (2002). A single P450 allele associated with insecticide resistance in Drosophila. Science 297, 2253-2256. doi: 10.1126/science. 1074170

Egli, D., Domènech, J., Selvaraj, A., Balamurugan, K., Hua, H., Capdevila, M., Georgiev, O., Schaffner, W., et al. (2006). The four members of the Drosophila metallothionein family exhibit distinct yet overlapping roles in heavy metal homeostasis and detoxification. Genes Cells 11, 647-658. doi: 10.1111/j.13652443.2006.00971.x

Fisher, M. A., and Oleksiak, M. F. (2007). Convergence and divergence in gene expression among natural populations exposed to pollution. BMC Genomics 8:108. doi: 10.1186/1471-2164-8-108 stressors and genetic differences between individuals may only be apparent under a complex set of environmental conditions (Whitehead and Crawford, 2006; Alvarez et al., 2015). Studies of novel systems in the wild or other complex stress conditions is likely, then, to identify novel resistance mechanisms (Colbourne et al., 2011; Alvarez et al., 2015).

\section{AUTHOR CONTRIBUTIONS}

All authors listed have made a substantial, direct and intellectual contribution to the work, and approved it for publication.

\section{FUNDING}

TM receives grant support from the Natural Sciences and Engineering Research Council (\#34146) and Canada Research Chairs Program (\#230113).

Glastad, K. M., Arsenault, S. V., Vertacnik, K. L., Geib, S. M., Kay, S., Danforth, B. N., Rehan, S. M., et al. (2017). Variation in DNA methylation is not consistently reflected by sociality in Hymenoptera. Genome Biol. Evol. 9, 1687-1698. doi: 10.1093/gbe/evx128

Glastad, K. M., Gokhale, K., Liebig, J., and Goodisman, M. A. D. (2016a). The casteand sex-specific DNA methylome of the termite Zootermopsis nevadensis. Sci. Rep. 6:37110. doi: 10.1038/srep37110

Glastad, K. M., Goodisman, M. A. D., and Soojin, V. Y. (2016b). Effects of DNA methylation and chromatin state on rates of molecular evolution in insects. G3 6, 357-363. doi: 10.1534/g3.115.023499/-/DC1

Guirola, M., Naranjo, Y., Capdevila, M., and Atrian, S. (2010). Comparative genomics analysis of metallothioneins in twelve Drosophila species. J. Inorg. Biochem. 105, 1050-1059. doi: 10.1016/j.jinorgbio.2011. 05.004

Hanikenne, M., and Nouet, C. (2011). Metal hyperaccumulation and hypertolerance: a model for plant evolutionary genomics. Curr. Opin. Plant Biol. 14, 252-259. doi: 10.1016/j.pbi.2011.04.003

Hull, J. J., Chaney, K., Geib, S. M., Fabrick, J. A., Brent, C. S., Walsh, D., and Lavine, L. C. (2014). Transcriptome-based identification of ABC transporters in the western tarnished plant bug Lygus hesperus. PLOS ONE 9:e113046. doi: 10.1371 /journal.pone.0113046

Janssens, T. K. S., Roelofs, D., and van Straalen, N. M. (2009). Molecular mechanisms of heavy metal tolerance and evolution in invertebrates. Insect Sci. 16, 3-18. doi: 10.1111/j.1744-7917.2009.00249.x

Kafel, A., Rozpędek, K., Szulińska, E., Zawisza-Raszka, A., and Migula, P. (2014). The effects of cadmium or zinc multigenerational exposure on metal tolerance of Spodoptera Exigua (Lepidoptera: Noctuidae). Environ. Sci. Pollut. Res. Int. 21, 4705-4715. doi: 10.1007/s11356-013-2409-z

Kägi, J. H. (1991). Overview of metallothionein. Methods Enzymol. 205, 613-626. doi: 10.1016/0076-6879(91)05145-L

Kharchenko, P. V., Alekseyenko, A. A., Schwartz, Y. B., Minoda, A., Riddle, N. C., Ernst, J., Sabo, P. J., et al. (2011). Comprehensive analysis of the chromatin landscape in Drosophila melanogaster. Nature 471, 480-485. doi: 10.1038/ nature 09725

Knee, J. M., Rzezniczak, T. Z., Barsch, A., Guo, K. Z., and Merritt, T. J. S. (2013). A novel ion pairing LC/MS metabolomics protocol for study of a variety of biologically relevant polar metabolites. J. Chromatogr. B 936, 63-73. doi: 10 . 1016/j.jchromb.2013.07.027

Le Goff, G., Boundy, S., Daborn, P. J., Yen, J. L., Sofer, L., Lind, R., Sabourault, C., Madi-Ravazzi, L., et al. (2003). Microarray analysis of cytochrome P450 mediated insecticide resistance in Drosophila. Insect Biochem. Mol. Biol. 33, 701-708. doi: 10.1016/S0965-1748(03) 00064-X 
MacMillan, H. A., Knee, J. M., Dennis, A. B., Udaka, H., Marshall, K. E., Merritt, T. J. S., and Sinclair, B. J. (2016). Cold acclimation wholly reorganizes the Drosophila melanogaster transcriptome and metabolome. Sci. Rep. 6:28999. doi: 10.1038/srep28999

Majumber, S., Kutay, H., Datta, J., Summers, D., Jacob, S. T., and Ghoshai, K. (2006). Epigenetic regulation of metallothionein-I gene expression: differential regulation of methylated and unmethylated promoters by DNA methyltransferases and methyl CpG binding proteins. J. Cell. Biochem. 97, 1300-1316. doi: 10.1002/jcb.20738

Mattingly, K. S., Beaty, B. J., Mackie, R. S., McGaw, M., Carlson, J. O., and RaymsKeller, A. (2001). Molecular cloning and characterization of a metal responsive chironomus tentans alpha-tubulin cDNA. Aquat. Toxicol. 54, 249-260. doi: 10.1016/S0166-445X(00)00181-8

Migula, P., Laszczyca, P., and Augustyniak, M. (2004). Antioxidative defence enzymes in beetles from a metal pollution gradient. Biologia 59, 645-654

Mireji, P. O., Keating, J., Hassanali, A., Impoinvil, D. E., Mbogo, C. M., Muturi, M. N., Nyambaka, H., et al. (2010a). Expression of metallothionein and $\alpha$ tubulin in heavy metal-tolerant Anopheles gambiae sensu stricto (Diptera: Culicidae). Ecotoxicol. Environ. Saf. 73, 46-50. doi: 10.1016/j.ecoenv.2009. 08.004

Mireji, P. O., Keating, J., Hassanali, A., Mbogo, C. M., Muturi, M. N., Githure, J. I., and Beier, J. C. (2010b). Biological cost of tolerance to heavy metals in the mosquito Anopheles gambiae. Med. Vet. Entomol. 24, 101-107. doi: 10.1111/j. 1365-2915.2010.00863.x

M'kandawire, E., Mierek-Adamska, A., Stürzenbaum, S. R., Choongo, K., Yabe, J., Mwase, M., Saasa, N., and Blindauer, C. A. (2017). Metallothionein from wild populations of the African catfish clarias gariepinus: from sequence, protein expression and metal binding properties to transcriptional biomarker of metal pollution. Int. J. Mol. Sci. 18:E1548. doi: 10.3390/ijms18071548

Musasia, F. K., Isaac, A. O., Masiga, D. K., Omedo, I. A., Mwakubambanya, R., Ochieng, R., and Mireji, P. O. (2013). Sex-specific induction of CYP6 cytochrome P450 genes in cadmium and lead tolerant Anopheles gambiae. Malar. J. 12:97. doi: 10.1186/1475-2875-12-97

Morgan, A. J., Kille, P., and Stürzenbaum, S. R. (2007). Microevolution and ecotoxicology of metals in invertebrates. Environ. Sci. Technol. 41, 1085-1096. doi: 10.1021/es061992x

Pedra, J. H. F., McIntyre, L. M., Scharf, M. E., and Pittendrigh, B. R. (2004). Genome-wide transcription profile of field- and laboratory-selected dichlorodiphenyltrichloroethane (DDT)-resistant Drosophila. Proc. Natl. Acad. Sci. U.S.A. 101, 7034-7039. doi: 10.1073/pnas.0400580101

Pérez-Rafael, S., Kurz, A., Guirola, M., Capdevila, M., Palacios, Ò., and Atrian, S. (2012). s MtnE, the fifth Drosophila metallothionein, functionally distinct from the other members of this polymorphic protein family? Metallomics 4, 342-348. doi: 10.1039/c2mt00182a

Poynton, H. C., Varshavsky, J. R., Chang, B., Cavigiolio, G., Chan, S., Holman, P. S., Loguinov, A. V., et al. (2007). Daphnia magna ecotoxicogenomics provides mechanistic insights into metal toxicity. Environ. Sci. Technol. 41, 1044-1050. doi: 10.1021/es0615573

Qiang, W., Huang, Y., Wan, Z., and Zhou, B. (2017). Metal-metal interaction mediates the iron induction of Drosophila MtnB. Biochem. Biophys. Res. Commun. 487, 646-652. doi: 10.1016/j.bbrc.2017.04.109

Raddatz, G., Guzzardo, P. M., and Olova, N. (2013). Dnmt2-dependent methylomes lack defined DNA methylation patterns. Proc. Natl. Acad. Sci. U.S.A. 10, 8627-8631. doi: 10.1073/pnas.1306723110

Reinders J., Wulff, B. B., Mirouze, M., Mari-Ordonez, A., Dapp, M., Rozhon, W., et al. (2009). Compromised stability of DNA methylation and transposon immobilization in mosaic Arabidopsis epigenomes. Genes Dev. 23, 939-950. doi: $10.1101 / \operatorname{gad} .524609$

Roelofs, D., Janssens, T. K. S., Timmermans, M. J. T. N., Nota, B., Mariën, J., Bochdanovits, Z., et al. (2009). Adaptive differences in gene expression associated with heavy metal tolerance in the soil arthropod Orchesella cincta. Mol. Ecol. 18, 3227-3239. doi: 10.1111/j.1365-294X.2009.04261.x
Salnikow, K, and Zhitkovich, A. (2008). Genetic and epigenetic mechanisms in metal carcinogenesis and cocarcinogenesis: nickel, arsenic, and chromium. Chem. Res. Toxicol. 21, 28-44. doi: 10.1021/tx700198a

Schmidt, J. M., Good, R. T., Appleton, B., Sherrard, J., Raymant, G. C., Bogwitz, M. R., Martin, J., et al. (2010). Copy number variation and transposable elements feature in recent, ongoing adaptation at the Cyp6g1 locus. PLOS Genet. 6:e1000998. doi: 10.1371/journal.pgen. 1000998

Shaw, J. R., Colbourne, J. K., Davey, J. C., Glaholt, S. P., Hampton, T. H., Chen, C. Y., Folt, C. L., et al. (2007). Gene response profiles for Daphnia pulex exposed to the environmental stressor cadmium reveals novel crustacean metallothioneins. BMC Genomics 8:477. doi: 10.1186/1471-21 64-8-477

Soetaert, A., Vandenbrouck, T., van der Ven, K., Maras, M., van Remortel, P., Blust, R., and De Coen, W. M. (2007). Molecular responses during cadmiuminduced stress in Daphnia magna: integration of differential gene expression with higher-level effects. Aquat. Toxicol. 83, 212-222. doi: 10.1016/j.aquatox. 2007.04.010

Sooksa-Nguan, T., Yakubov, B., Kozlovskyy, V. I., Barkume, C. M., Howe, K. J., Thannhauser, T. W., Rutzke, M. A., et al. (2009). Drosophila ABC transporter, DmHMT-1, confers tolerance to cadmium. DmHMT-1 and its yeast homolog, SpHMT-1, are not essential for vacuolar phytochelatin sequestration. J. Biol. Chem. 284, 354-362. doi: 10.1074/jbc.M806501200

Southon, A., Burke, R., and Camakaris, J. (2013). What can flies tell us about copper homeostasis? Metallomics 5, 1346-1356. doi: 10.1039/c3mt00105a

Stone, D., Jepson, P., Kramarz, P., and Laskowski, R. (2001). Time to death response in carabid beetles exposed to multiple stressors along a gradient of heavy metal pollution. Environ. Pollut. 113, 239-244. doi: 10.1016/S02697491(00)00134-2

Trible, W., Olivos-Cisneros, L., McKenzie, S. K., Saragosti, J., Chang, N. -C., Matthews, B. J., Oxley, P. R., and Kronauer, D. J. C. (2017). Orco mutagenesis causes loss of antennal lobe glomeruli and impaired social behavior in ants. Cell 170, 727-735.e10. doi: 10.1016/j.cell.2017.07.001

Valko, M., Jomova, K., Rhodes, C. J., Kuča, K., and Musílek, K. (2015). Redox- and non-redox-metal-induced formation of free radicals and their role in human disease. Arch. Toxicol. 90, 1-37. doi: 10.1007/s00204-0151579-5

Valko, M., Morris, H., and Cronin, M. T. D. (2005). Metals, toxicity and oxidative stress. Curr. Med. Chem 12, 1161-1208. doi: 10.2174/0929867053 764635

van Straalen, N. M., Janssens, T. K. S., and Roelofs, D. (2011). Microevolution of toxicant tolerance: from single genes to the genome's tangled bank. Ecotoxicology 20, 574-579. doi: 10.1007/s10646-0110631-3

Whitehead, A., and Crawford, D. L. (2006). Neutral and adaptive variation in gene expression. Proc. Natl. Acad. Sci. U.S.A. 103, 5425-5430. doi: 10.1073/pnas. 0507648103

Wu, Z., Du, Y., Xue, H., Wu, Y., and Zhou, B. (2012). Aluminum induces neurodegeneration and its toxicity arises from increased iron accumulation and reactive oxygen species (ROS) production. Neurobiol. Aging 33, 199.e1-12. doi: 10.1016/j.neurobiolaging.2010.06.018

Conflict of Interest Statement: The authors declare that the research was conducted in the absence of any commercial or financial relationships that could be construed as a potential conflict of interest.

Copyright (c) 2017 Merritt and Bewick. This is an open-access article distributed under the terms of the Creative Commons Attribution License (CC BY). The use, distribution or reproduction in other forums is permitted, provided the original author(s) or licensor are credited and that the original publication in this journal is cited, in accordance with accepted academic practice. No use, distribution or reproduction is permitted which does not comply with these terms. 